\title{
Corporate Distress Prediction Using a Hybrid of Accounting and Option Based Model
}

\author{
KHALID MUMTAZ KHAN \\ Ph.D. Scholar, Bahria University, E-8, Shangrilla road, Islamabad, Pakistan. \\ E-mail: Khalid@bahria.edu.pk / khalidmumtazmail@gmail.com \\ Tel: +92 3008508050
}

\begin{abstract}
The crash of global financial markets is evident of the Corona Virus Disease 2019 (COVID-19) led economic recession shaping into an imminent financial crisis now. The identification of firms prone to default in such crisis in important to keep the investors confiding in the financial markets. This study presents a hybrid model to preemptively identify the financially distressed firms which are expected to default. The hybrid model has been constructed by infusion of accounting variables into and option based financial model, hence seeing the default phenomenon in a hindsight as well as foresight. A sample of 30 housing sector firms listed at New York Stock Exchange (NYSE. Area Under Curve (AUC) methodology has been used to evaluate the results of the hybrid model. The results show that the proposed hybrid model has the highest AUC in comparison with either of accounting information or option based model, alone. The study concludes at a comparatively better ability of the hybrid model in anticipating financial stress among the firms and recommends the same to be used for identification of firms prone to default. An out of sample testing of the proposed hybrid model has been mentioned as the future research to evaluate its efficacy out of the restrictive assumptions of this study.
\end{abstract}

Keywords: Financial Distress, Default, Accounting Based Models, Option Based Models, Hybrid Model, US Housing Sector.

\section{Introduction}

The crash of Crude Brent futures market into a negative price zone is evident of the COVID-19 induced turbulence in the markets. This turbulence is more than expected to result in a financial crisis (Fernandes, 2020). International Monetary Fund has already forewarned a crisis worse than the 2008-2010 financial crisis (Baldwin \& Tomiura, 2020). Such crisis results in foreclosures, bankruptcies, and defaults. An early warning to such defaults enables the stakeholders to reposition their stakes in the defaulting firms and business sectors. Financial distress is one of the early warning symptoms of default (Altman, 1993). Identification of financially distressed firms is important to predict the probable default and safeguarding the interest of stake holders along with maintaining investors trust in the financial markets (Gitman, 1996). Past research on default prediction is generally industry specific rather than firm specific (Sanobar, 2012). It has been observed that firms' default leads to industry default rather than vice-versa. This establishes the need for existence of a readily usable corporate default prediction model for the firms to use for assessing the degree of financial distress which may lead to default. Onur and Simga (2018) observe that most of the models in use to date from the financial statements and their supplementary notes. Despite due criticism on the accounting information for its purpose, procedure, and practice, it is widely used as a reliable input in default prediction models (Panigrahi, Raul \& Gijare, 2018). Since there is a certain amount of flexibility in provisioning and estimation of certain accounting figures, firms having similar financial statement, may not carry similar financial problems and reveal the same symptoms of financial distress. The financial statements reflect past information and are subject to manipulation (Sayari \& Simga, 2016). The audited 
financial statements of any firm are released once a year for reporting purpose, and not with the purpose of ascertaining the degree of financial distress. While using information from the financial statements the accounting information based corporate default prediction models tend to ignore the purpose, procedure, and element of estimation in such information (Kementerian Republik Indonesia, 2018). Therefore, these models yield similar results for the financial distress while the firms may have the uniqueness in their degree and characteristics of financial distress. Specially in market scenarios such as COVID-19 the accounting based models face an acute restriction to their default prediction ability. An alternate approach is the use market information to identify the financially distressed firms, i.e., the option-based models.

The option-based models are derived from the option pricing theory to calculate the default probability. The Merton's option-based models are in stark contrast with the models based on accounting information, such as Altman (1968), Ohlson (1980). The essential difference between both these generations of models is that the earlier depicts firm default by using option-pricing equations rather than indulging into the data mining from the accounting records of the firm, like the later does (Agarwal, \& Taffer, 2008). Meaning there by that the option-based models would consider the price of firm's shares in the market, its liabilities, and interest rate, while the accounting-based models would attempt to find out a default pattern form the historical accounting records of the firm (Pratap \& Kumar, 2016).

Both types of models have their respective shortfalls. The accounting-based models suffer from the infrequent availability and obsolescence of accounting information, not catering for the current or the futuristic view (Grice \& Ingram, 2001; Celli, 2015). Also, the difference in purpose, procedure, and the estimation with which accounting information is framed, may make it less usable for ascertaining degree of financial distress in a firm (Philosophov \& Philosophov, 2002).

The option-based models assume the existence of the efficient-market-hypothesis (EMH), where the firms' stock price should be reflective of all the information about a firm, while this may not be case in real (Chava \& Jarrow, 2004). The review of relevant literature reveals that markets may be experiencing a strong, semi-strong, or a weak form of EMH (Chen, Huang \& Lin, 2009). Therefore, the model may hold good only when a market is in a state of strong EMH, while limiting its application when the market is in weak or semi strong state.

The option-based models suffer from market inefficiency, while the accounting-based models suffer from lagged accounting information. Based on these limitations, this study proposes a hybrid model, which has been based on the predictive strengths of both generations of models, i.e. option based, and accounting based. The hybrid model has been constructed by simply infusing accounting information into an optionbased model.

The predictive performance of hybrid model has been empirically validated through its testing on the sample taken from the financially distressed firms in the U.S. housing sector. It the same sector which was partly blamed for the subprime mortgage crisis Dec 2007- June 2009 in the U.S. (Demyanyk \& Hemert, 2011).

\section{The Study Objectives}

Objectives of this study include the following.

a. Evaluate the sufficiency of Accounting based models to predict firm default.

b. Evaluate the sufficiency of Option based model to predict firm default.

c. Construct a hybrid model based on accounting information (ratios) and financial information (options, as derivative instrument).

d. Evaluate the hybrid model for its sufficiency to predict firm default. 


\section{The Scope of Study}

This study limits its scope the firms in housing sector listed at New York Stock Exchange (NYSE). The scope has been kept limited to this sector for the reason of its significance in providing the underlying assets for the financial markets, including the derivative instruments. This study is based on the collected data for five years i.e., 2014 to 2019. Major scope of study is to:

a. Measure financial distress on the firms listed in housing sector at NYSE.

b. Ascertain the likelihood of financial distress leading to corporate default in the firms listed in the housing sector at NYSE, using the hybrid model

\section{The Central Research Question}

This study evaluates the sufficiency of Accounting based models and the Option based models for predicting the firms default and converges both models to compliment respective strength of each type of the model. The convergence results in a hybrid model and testing the efficacy of such a model in terms of its enhanced ability to anticipate firm default remains the key curiosity of this study which may be framed as the following research question.

a. Does the hybrid model predict corporate distress better than Accounting based model and Option based model in their respective standalone ability to foresee such distress?

\section{Literature Review}

Presently, the literature presents an array of models which have been established over the due course of time. These models have been developed through thesis and anti-thesis on the phenomenon of predict bankruptcy and corporate defaults.

Though the models have been developed considering the best predictor of bankruptcy, however for the convenience of bankruptcy stakeholders these models have been classified into the following categories. The following table summarizes the models within each category.

Table 1: Summary of models within each category

\begin{tabular}{|l|l|l|}
\hline \multicolumn{1}{|c|}{ Statistical Models } & \multicolumn{1}{|c|}{ Artificial Intelligence Models } & \multicolumn{1}{|c|}{ Theoretical Models } \\
\hline $\begin{array}{l}\text { Univariate models (Altman 1993, } \\
\text { Morris, 1998) }\end{array}$ & $\begin{array}{l}\text { Recursively Partitioned Decision } \\
\text { Trees (Freidman, 1977; Pompe } \\
\text { and Feelders, 1997), }\end{array}$ & $\begin{array}{l}\text { Balance Sheet Decomposition } \\
\text { Measures (BSDM) / entropy } \\
\text { theory (Theil, 1969; Lev, 1973; } \\
\text { Booth, 1983), }\end{array}$ \\
\hline $\begin{array}{l}\text { Multiple Discriminant Analysis } \\
\text { (MDA)Models (Klecka, 1981; } \\
\text { Altman, 1993; Morris, 1998) }\end{array}$ & $\begin{array}{l}\text { Case Based Reasoning (CBR) } \\
\text { Models (Kolonder, 1993), }\end{array}$ & $\begin{array}{l}\text { Gambler Ruin Theory (see Scott, } \\
1981 ; \text { Morris, 1998), }\end{array}$ \\
\hline $\begin{array}{l}\text { Linear Probability Models (LPM) } \\
\text { (Maddala, 1983; Theodossiou, } \\
\text { 1991; Gujarati, 1998; Morris, } \\
\text { 1998), }\end{array}$ & $\begin{array}{l}\text { Neural Networks (Salchenberger } \\
\text { 1993; Yang } \text { et al., 1999), }\end{array}$ & $\begin{array}{l}\text { Cash Management Theory (Aziz } \\
\text { et al., 1988; Laitinen and } \\
\text { Laitinen, 1998), }\end{array}$ \\
\hline $\begin{array}{l}\text { Logit Models (Maddala, 1983; } \\
\text { Theodossiou, 1991; Gujarati, } \\
\text { 1998; Morris, 1998) }\end{array}$ & $\begin{array}{l}\text { Genetic Algorithms (Shin and } \\
\text { Lee, 2002; Varetto, 1998), }\end{array}$ & $\begin{array}{l}\text { Credit Risk Theories (including } \\
\text { JPorgan's Credit Metrics, } \\
\text { Moody's KMV Model (Black and } \\
\text { Scholes, 1973; Merton, 1973) }\end{array}$ \\
\hline $\begin{array}{l}\text { Probit Model (Maddala, 1983; } \\
\text { Theodossiou, 1991; Gujarati, }\end{array}$ & $\begin{array}{l}\text { Rough Sets Model (Pawlak, } \\
\text { 1982; Ziarko, 1993; Dimitras et }\end{array}$ & $\begin{array}{l}\text { CSFB's Credit Risk (Credit } \\
\text { Suisse, 1997), }\end{array}$ \\
\hline
\end{tabular}




\begin{tabular}{|l|l|l|}
\hline 1998; Morris, 1998), & al., 1999). & \\
\hline $\begin{array}{l}\text { Cumulative Sums (CUSUM) } \\
\text { Model (Page, 1954; Healey, }\end{array}$ & & McKinsey’s Credit Portfolio \\
1987, Kahya and Theodossiou, & & View (Wilson, 1997a b, 1998). \\
1999), & \\
\hline $\begin{array}{l}\text { Partial Adjustment Processes } \\
\text { (Laitinen and Laitinen, 1998; }\end{array}$ & & \\
Gujarati, 1998; Gujarati, 1998). & & \\
\hline
\end{tabular}

Source: Author

Such a wide range and generations of models make it difficult for the analysts, practitioners, and researchers to choose one best model to effectively identifying the financially distressed firms. This study adopts logistic regression model as the representative of accounting information-based financial distress detection model for comparison with the option-based model. Later both models are integrated to create a hybrid model and this model has then been assessed for its improved ability to identify the financially distressed firms in the U.S. housing sector.

\section{Research Methodology}

This study involves the in-depth study and attempt to explain the complex phenomenon of corporate default prediction. It is primarily based on testing of the exiting hypothesis for any of the Accounting or Option based models' supremacy over the other in predicting corporate default. This includes the specification and identification of any relationship existing between the two types of models and based on this proposition of a hybrid model to overcome the short comings, if any, among these models. Therefore, analytical research has been the prime methodology for this study.

Since it has been argued that in order to explain the phenomenon of corporate default in its totality one needs to include significant elements by factoring them in to a model, accounting information pertinent to corporate default prediction has been factored into the market information based corporate default prediction model. The emerging model named as hybrid model has been tested on the data to ascertain if the results of such model are better than the two types analyzed earlier for the purpose of predicting corporate default.

\section{Data Collection}

This study has extracted the requisite information for the Accounting based models from the Composted industrial file, and the information for the option-based models has been obtained from the Center for Research in Security Prices (CRSP) database. The Firm's equity at its market value (Ve) has been computed through taking a market price of firm's shares and the number of outstanding shares. Interest rate on the T-Bills has been used as risk-free rate.

\section{Tools used for the study:}

The tools used for the study are listed as follows.
a) Altman Z score.
b) Ohlson O score.
c) Option based model. 


\section{Data Analysis and Interpretation}

The accounting variables have been selected in the light their significance in the predicting corporate default while reviewing of relevant literature. The variables are in consistency with the ones mentioned in previous studies (Bal, G.R., and Raja, S., 2014, Bhatt N Suyas., 2012, Amendoala, et. Al., 2011, Altman, E., 1984, Beaver, W., 1966, Altman, E., 1968). These variables have been shown in table 1.

Table 2: Accounting variables selected for forward step-wise logistic method

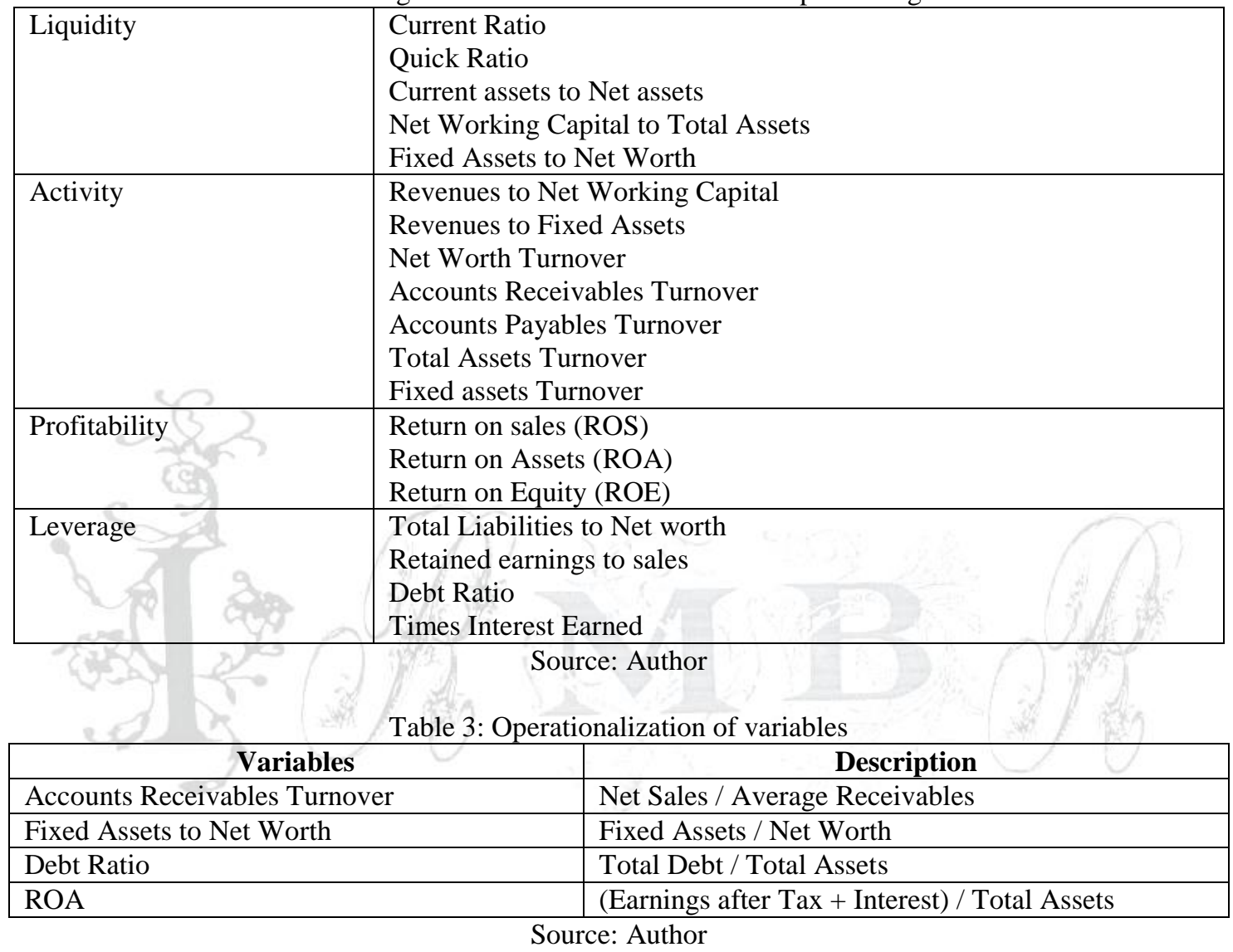

This study avoids 'over fitting' of the model through a forward stepwise logistic method to select limited number of variables that yield a model. Table 1 provides valuable insight to the bankruptcy prediction in housing sector of the U.S. Many variables may lead to an over-fitted model. This over fitness might make a model in-sample performing.

Table 4: Estimation of the coefficients for the hybrid model.

\begin{tabular}{|c|c|c|c|}
\hline Intercept & Coefficient & S.E. & VIF \\
\hline$X_{1}$ & -5.8234 & 0.665 & 1.141 \\
\hline$X_{2}$ & 3.884 & 0.616 & 1.085 \\
\hline$X_{3}$ & -2.435 & 0.840 & 1.006 \\
\hline$X_{4}$ & .008 & 0.007 & 1.043 \\
\hline$X_{5}$ & 1.503 & .913 & 1.005 \\
\hline
\end{tabular}

Source: Author 
The model may experience poorly once applied out of sample. Nevertheless, this is the process of developing deeper understanding of the corporate default phenomenon. The selected ratios and variables compared and drawn in an accounting model yield the result mentioned in Table 3.

\section{Hybrid Model and its Input Variables}

The models based on financial option, and financial ratios, both have their unique strengths and respective weaknesses (Parker, Gary, Peters \& Turetsky, 2002). Option based models incorporate the latest information reflected in the stock price of the firm (Wu, Gaunt \& Gray, 2010). This reflection may sometimes be under / over reflection depending upon the form of efficient market hypothesis the industry is experiencing at a certain point in time. Thus, the form of EMH may influence the performance of model (Zavgren \& Friedman, 1988).

On the other hand, accounting information may be lagged but to date financial statements have their proven ability to present the financial health of a firm. The information being lagged, conservative, and prudent in nature may not include the market information which option-based models do.

Considering the strengths and weaknesses of both types of models, this study has established a Hybrid model. This model has resilience, reliability, and hindsight of that of the Accounting model, and foresightedness of that an Option based model. The model is presented as below.

$$
\mathrm{PB}=\mathrm{P}(\mathrm{y}=1 \mid \mathrm{x})=1 / 1+\exp \left(-\mathrm{w} \cdot \mathrm{x}-\mathrm{B}_{0}\right)
$$

Where

$$
\text { w. } x=B_{1} X_{1}+B_{2} X_{2}+B_{3} X_{3}+B_{4} X_{4}+B_{5} X_{5}
$$

$\mathrm{X} 1=$ Probability of default from the option-based model

$\mathrm{X} 2=\mathrm{ROA}$

$\mathrm{X} 3=$ Fixed asset to net worth

$\mathrm{X} 4=$ Debt Ratio

$\mathrm{X} 5=$ Accounts receivable turn over

\section{Logistic Regression Model}

The logistic regression model is a statistical modeling technique, which seeks the relationship between the selected independent variables, and a binary dependent variable (Jitender et. Al., 2011). The binary dependent variable in this case would be $(0,1)$ representing a firm either in financial distress or otherwise. The development of logit regression models can be tracked back to Ohlson (1980), the first one to attempt predicting bankruptcy using logit model. This was followed by Jaselskis, E.J, and Ashley (1991). The models have been tested largely on samples comprising of the contracting firms in the construction business.

The model works as $\mathrm{y}_{\mathrm{i}} \in\{0,1\}$ for all $\mathrm{i}=1$ to $\mathrm{n}$. ( $\mathrm{n}=$ the number of samples). Logistic regression model estimates the probability that the label is 1 for a given example $\mathrm{x}$ using the model (Belliot, T. and Crook, J. 2006)

$$
\mathrm{P}(\mathrm{y}=1 \mid \mathrm{x})=1 / 1+\exp \left(-\mathrm{w} \cdot \mathrm{x}-\mathrm{B}_{0}\right)
$$

The estimation for parameters $\mathrm{B}_{0}$ and $\mathrm{w}$ is done through the procedure of maximum likelihood procedure. To maximize the log-likelihood function with respect to $\mathrm{B}_{\mathrm{o}}$ and $\mathrm{w}$

$$
\mathrm{L}\left(\mathrm{x}_{1}, \ldots \ldots, \mathrm{x}_{\mathrm{n}} \mid \mathrm{w}, \mathrm{B}_{0}\right)=\mathrm{E}_{\mathrm{i}=1}^{\mathrm{n}} \mathrm{ylog} \mathrm{p}_{\mathrm{i}+}\left(1-\mathrm{y}_{\mathrm{i}}\right) \log \left(1-\mathrm{p}_{\mathrm{i}}\right)
$$


Where

$$
\mathrm{p}_{\mathrm{i}}=\mathrm{P}\left(\mathrm{y}|=1| \mathrm{x}_{\mathrm{i}}\right)
$$

\section{The Option-Based Model}

The use of options in evaluating various financial instruments and investment opportunities is not unprecedented. The use of options is becoming increasingly frequent in assessing corporate bankruptcy. Campbell, Hilscher and Szilagyi, (2008) propose to view the equity of a firm as European Option on the market value of firm's assets, while the book value is to be the Strike Price, in a levered firm.

The firm would exist till the book value of firm's liabilities is less than value of assets, and vice versa (Dichev, 1998) The stockholders may exercise the option of disposing off the assets of firm before the firm files for bankruptcy, but once the value goes below the strike price, which in this case is the book value of firms' liabilities, the option may not be exercisable.

The above discussion may be modelled into the Black-Scholes-Merton (Collins, 1980; Sandin \& Porporato, 2007) where market value of firm's equity (Ve) is a European call option on the value of the firms' assets.

It can be written in form of the following equation:

$\mathrm{Ve}=\mathrm{VaN}(\mathrm{d} 1)-\mathrm{XeN}(\mathrm{d} 2)$

Where

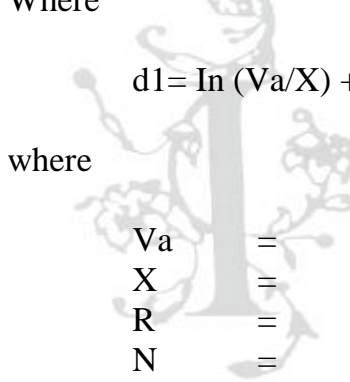

Firms experiencing bankruptcy would generally have a negative equity. The book value of liabilities would exceed the value of assets, and usually lies between the book value of non-current, and the current liabilities (Shumway, 2001). The review of relevant literature reveals that usually the affirmative default occurs when the current liabilities plus one half of the long-term liabilities equals to the value of assets (Jitender et. Al., 2011; Turetsky \& McEwan, 2001).

The fraction of the long-term liabilities, just stated, may be adjusted to the industry specific characteristics. For the purpose of this study, the one-half fraction has been used in the model to foresee default. The strike price $(\mathrm{X})$ of the option has been set at a value equal to book value of current liabilities plus one half of the book value of the long-term liabilities. The fraction may be adjusted for addressing industry specific default symptoms and patterns.

To obtain the realistic outcome of default prediction an iterative computation of the SDa is suggested (Jitender et. Al., 2011). The daily Ve for the past year has been used to compute an estimated volatility of the equity SD, which is assumed to be the initial estimate for the SD in the value of the firm's assets.

This initial estimate may be used in solving the Black-Scholes equation. The purpose is to obtain the estimate for daily $\mathrm{Va}$, consequently computing the standard deviation in the daily return for the Va. This 
would become the new estimate for SDa for next iteration. The iteration may be repeated till the value of SDa converges to 0.0001 and the daily Va can be solved through equation 3 .

While using the framework of an option-based model the probability of bankruptcy (PB) may be considered as the market value of firm's assets falling below the face value of the firm's liabilities at a certain time T. Assuming the return on the firm's assets to be normally distributed, the PB may be computed as equation 4 :

$$
\mathrm{PB}=\mathrm{N}[\mathrm{In}(\mathrm{Va} / \mathrm{X})+(\mathrm{u}-1 / 2 \mathrm{SD}) \mathrm{T} / \mathrm{SD} . \mathrm{T}]
$$

Pertinent to mention that the underlying assumption in the way of computing PB is the risk neutrality, assuming at least a risk free rate expected growth in all the assets. Though the return on firm's assets is supposed to have a normal distribution, the PB depends upon the actual distribution of the assets' values, which is a function of the actual return on assets of the firm, computed from the daily value of the assets.

\section{Results, Interpretation, and Discussion}

This study adopts Receiver Operating Characteristic (ROC) curve to evaluate the performance of the hybrid model. This is in consistency with the same technique being adopted to evaluate the efficacy of the Accounting based models and the Option based models, respectively. A higher AUC represents better predictive power of the model to foresee bankruptcies. Theoretically, an AUC value of 1 is taken as absolute ability to predict. The model has been run on the selected sample and yielded the results summarized in the following table.

\begin{tabular}{|c|c|} 
Table 5: Predictive power of various models \\
\hline Models & Area Under Curve (AUC) \\
\hline Logistic Regression - All 19 variables & 0.6234 \\
\hline Logistic Regression - Selected 4 variables & 0.7638 \\
\hline Option - based model & 0.8514 \\
\hline Hybrid model (proposed in this study) & 0.8836 \\
\hline
\end{tabular}

Source: Author

The results are consistent with the argument that both models independently suffer from conflicting assumptions. Once infused into a hybrid model, the conflict between an Accounting based model and an Option based model rather has been observed to complement each model's shortcomings.

Pertinent to mention that the information in the financial statements of firm is tailored for reporting to the stakeholder about the financial position of the firm rather than contending the probability of filing bankruptcy / facing default. Therefore, the information in the financial statements needs to be reorganized for seeing the bankruptcy probability of the firm, which may be done through modeling this information. Furthermore, the financial statements contain quantitative information and pay less heed to qualitative factors, while the bankruptcy occurrence is factored not only to the quantitative factors, but the qualitative factors too. Though the option-based model solves the problem, but the application of option-based model is limited, and subject to provision of certain assumptions, particularly the efficient market hypothesis.

The combination of accounting based, and the accounting information-based model for predicting bankruptcy, the firms prone to bankruptcy can be identified earlier with better precision as to their probability of bankruptcy. 


\section{Conclusion}

Though significant has been carried out on the bankruptcy prediction model, but data for housing sector in the United States has sparingly been used in any sample. Most of the studies use sample from the financial sector, for a reason that the frequency with which brokers / speculators trade the financial assets is more as compared to the real assets. The fact that market stability in the longer run may only be assured once the foresight about the valuation of underlying assets is reliable.

This paper has measured the default risk of the housing sector in the United States, using the reliable bankruptcy prediction models, and has come up with a hybrid model to identify the firms under that degree of financial distress which may lead to bankruptcy.

The hybrid model contains the reliability of an accounting information-based model, and the incorporation of market information as an option-based model. The results show that the proposed hybrid model has highest AUC, meaning there by that it covers a wider spectrum of the factors causing financial distress leading to bankruptcy.

\section{Recommendations}

In backdrop of the models analyzed, and the data processed during this study it is suggested that.

a. The phenomenon of corporate default may not be considered attributable to any specific school of thought, though the major reason may be classified as financial or non-financial, and quantitative or qualitative.

b. In order to develop a holistic understanding of why firms default, and how such default can be preempted for precision in its probability and distance to actual event, all the relevant variables triggering such default may be factored into a workable model. Such factoring to model in way that the modular algorithm is usable in hands of the practitioners.

c. Hybrid model factors in both quantitative and qualitative variables causing default. Such model predicts corporate default better that a quantitative or a qualitative model in its standalone capacity

d. To foresee default with better precision in probability, and from a distance in terms of time from the occurrence of actual default, hybrid models should be used more often.

\section{Limitation and Future Research}

The study has limitation to its in-sample testing of the proposed model, while an out of the sample testing in proposed as an area for future research. Furthermore, the methodological limitation to the analytical research, opted in this study, may also be altered to interpret the outcome in manner different from that of this study.

\section{References}

Agarwal, V., \& Taffler, R. (2008). Comparing the performance of market-based and accounting-based bankruptcy prediction models. Journal of Banking \& Finance, 32(8), 1541-1551.

Altman, E. I. (1968). Financial ratios, discriminant analysis and the prediction of corporate bankruptcy. The journal of finance, 23(4), 589-609.

Altman, E. I. (1984). The success of business failure prediction models: An international survey. Journal of Banking \& Finance, 8(2), 171-198.

Altman, E. I., \& Hotchkiss, E. (1993). Corporate financial distress and bankruptcy.

Altman, E. I. (1968). Financial ratios, discriminant analysis and the prediction of corporate bankruptcy. The journal of finance, 23(4), 589-609. 
Amendola, A., Bisogno, M., Restaino, M., \& Sensini, L. (2011). Forecasting corporate bankruptcy: empirical evidence on Italian data. EuroMed Journal of Business.

Bal, G., Rao, N., \& Raja, S. (2013). Evidences of Financial Shenanigans from Past and Techniques to Predict Earnings Management and Solvency Position: A Case Study of IOCL. Available at SSRN 2208368.

Baldwin, R., \& Tomiura, E. (2020). Thinking ahead about the trade impact of COVID-19. Economics in the Time of COVID-19, 59.

Beaver, W. H. (1966). Financial ratios as predictors of failure. Journal of accounting research, 71-111.

Singh, B. P., \& Mishra, A. K. (2016). Re-estimation and comparisons of alternative accounting-based bankruptcy prediction models for Indian companies. Financial Innovation, 2(1), 6.

Bhatt, S. N. (2012). Capital structure and turnaround strategies using altman's Z-score models. Asian Journal of Research in Business Economics and Management, 2(7), 102-113.

Campbell, J. Y., Hilscher, J., \& Szilagyi, J. (2008). In search of distress risk. The Journal of Finance, 63(6), 2899-2939.

Celli, M. (2015). Can Z-Score Model Predict Listed Companies' Failures in Italy? An Empirical Test. International Journal of Business and Management, 10(3), 57.

Chava, S., \& Jarrow, R. A. (2004). Bankruptcy prediction with industry effects. Review of Finance, 8(4), 537-569.

Chen, H. J., Huang, S. Y., \& Lin, C. S. (2009). Alternative diagnosis of corporate bankruptcy: A neuro fuzzy approach. Expert Systems with Applications, 36(4), 7710-7720.

Collins, R. A. (1980). An empirical comparison of bankruptcy prediction models. Financial Management, 52-57.

Demyanyk, Y., \& Van Hemert, O. (2011). Understanding the subprime mortgage crisis. The review of financial studies, 24(6), 1848-1880.

Dichev, I. D. (1998). Is the risk of bankruptcy a systematic risk? the Journal of Finance, 53(3), 11311147.

Fernandes, N. (2020). Economic effects of coronavirus outbreak (COVID-19) on the world economy. Available at SSRN 3557504.

Gitman, L. J., Juchau, R., \& Flanagan, J. (2015). Principles of managerial finance. Pearson Higher Education AU.

Richardson, G., Taylor, G., \& Lanis, R. (2015). The impact of financial distress on corporate tax avoidance spanning the global financial crisis: Evidence from Australia. Economic Modelling, 44, 4453.

Grice, J. S., \& Ingram, R. W. (2001). Tests of the generalizability of Altman's bankruptcy prediction model. Journal of Business Research, 54(1), 53-61.

Oz, I. O., \& Simga-Mugan, C. (2018). Bankruptcy prediction models' generalizability: Evidence from emerging market economies. Advances in accounting, 41(C), 114-125.

Indonesia, K. R. (2019). Kontribusi Besar Industri Hasil Tembakau Bagi Ekonomi Nasional.

Kumar, J., Pal, K., Mahapatra, S. N., \& Kundu, S. S. (2011). Altman's model for predicting business failure: case study of HAFED. Abhigyan, 29(3), 52-62.

Takahashi, M., Taques, F. H., \& Basso, L. (2018). Altman's Bankruptcy Prediction Model: Test on a Wide Out of Business Private Companies Sample. iBusiness, 10(01), 21.

Sayari, N., \& Mugan, C. S. (2017). Industry specific financial distress modeling. BRQ Business Research Quarterly, 20(1), 45-62.

Panigrahi, C. M. A. (2018). Liquidity-Profitability Trade-Off: A Game of Survival and Growth. NMIMS Management Review, 36(1).

Panigrahi, C. M. A. (2017). Working capital management efficiency of Indian cement industry. NMIMS Journal of Economics and Public policy, 2.

Panigrahi, C. M. A., Raul, N., \& Gijare, C. (2018). Liquidity and profitability trade-off: A study of Indian pharmaceutical companies. NMIMS Journal of Economics and Public Policy, 3(1). 
Philosophov, L. V., \& Philosophov, V. L. (2002). Corporate bankruptcy prognosis: An attempt at a combined prediction of the bankruptcy event and time interval of its occurrence. International Review of Financial Analysis, 11(3), 375-406.

Pompe, P. P., \& Bilderbeek, J. (2005). The prediction of bankruptcy of small-and medium-sized industrial firms. Journal of Business venturing, 20(6), 847-868.

Prabowo, S. C. B. (2019). Analysis On The Prediction Of Bankruptcy Of Cigarette Companies Listed In the Indonesia Stock Exchange Using Altman (Z-score) Model And Zmijewski (X-score) Model. Jurnal Aplikasi Manajemen, 17(2), 254-260.

Madonna, S., \& Cestari, G. (2015). The accuracy of bankruptcy prediction models: a comparative analysis of multivariate discriminant models in the Italian context.

Sandin, A. R., \& Porporato, M. (2007). Corporate bankruptcy prediction models applied to emerging economies. International Journal of Commerce and Management.

Anjum, S. (2012). Business bankruptcy prediction models: A significant study of the Altman's Z-score model. Available at SSRN 2128475.

Shumway, T. (2001). Forecasting bankruptcy more accurately: A simple hazard model. The journal of business, 74(1), 101-124.

Parker, S., Peters, G. F., \& Turetsky, H. F. (2002). Corporate governance and corporate failure: a survival analysis. Corporate Governance: The international journal of business in society.

Turetsky, H. F., \& McEwen, R. A. (2001). An empirical investigation of firm longevity: A model of the ex ante predictors of financial distress. Review of Quantitative Finance and Accounting, 16(4), 323-343.

Wu, Y., Gaunt, C., \& Gray, S. (2010). A comparison of alternative bankruptcy prediction models. Journal of Contemporary Accounting \& Economics, 6(1), 34-45.

Zavgren, C. V., \& Friedman, G. E. (1988). Are bankruptcy prediction models worthwhile? An application in securities analysis. Management International Review, 34-44. 